\title{
Muitos votantes e poucos eleitores a difícil conquista da cidadania operária
no Brasil Império (Salvador, 1850-1881)*
}

\author{
Many voters and few electors \\ the difficult conquest for workers citizenship \\ in Imperial Brazil (Salvador, 1850-1881)
}

ALDRIN ARMSTRONG SILVA CASTELLUCCI** Programa de Pós-Graduação em História Regional e Local Universidade do Estado da Bahia

Salvador (BA)

Brasil

RESUMO Partindo do pressuposto de que a aquisição de direitos políticos é um passo decisivo para a conquista da cidadania, analisamos o envolvimento dos trabalhadores da cidade do Salvador com as eleições no Brasil Império no período de 1850 a 1881. Nossa pesquisa focaliza o papel e o peso do voto operário no processo eleitoral em uma sociedade escravista. O marco temporal final é o ano de aprovação da Lei Saraiva, por meio da qual foram feitas profundas alterações no sistema político e eleitoral vigente no país até então, com impactos diretos sobre o status dos libertos.

Palavras-chave cidadania, eleições, classe operária

ABSTRACT Considering political rights as a decisive advance to acquire citizenship, we analyse workers' involvement in the elections in Salvador

* Artigo recebido em: 01/11/2012. Aprovado em: 02/01/2013.

** Contato: acastellucci@uneb.br. 
from 1850 to 1881, during the Empire of Brazil (1822-1889). The research focuses on the role and strength of the workers' vote in the electoral process of a slave society. The final timeframe, 1881, was marked by the approval of the Lei Saraiva (Saraiva Law), which radically changed the political and electoral systems in the country, and had a direct impact on the status of freed persons.

Keywords citizenship, elections, working class

\section{Introdução}

Somos decididos adversários do sufrágio universal. (...)

A escola ultrademocrática, vítima eterna de absurdas e extravagantes ilusões, jamais refletirá nas lições da experiência e nos ditames da razão. As massas populares, altamente indiferentes ou apaixonadas e desvairadas, serão sempre o instrumento cego de todos os despotismos e nunca a base segura e sólida em que repouse o edifício trabalhoso e delicado do governo constitucional representativo, única forma, até hoje possível da verdadeira liberdade. A eleição neste regime é a origem de toda a direção social; dela saem os legisladores, os fiscais do governo e o próprio governo; dela emanam e nela fenecem todos os poderes sociais. Não é das trevas, da ignorância, das abusões, das paixões selvagens e brutais que surgirá o reinado da razão e da justiça na sociedade. Se a escola ultrademocrática é incorrigível, não é de recear, porém, que a luz da civilização deixe de iluminar o espírito público sobre a verdadeira liberdade.

Francisco Belisário Soares de Souza, 1872. ${ }^{1}$

Um verdadeiro abismo social separava Francisco Belisário Soares de Souza da maioria da população que habitava o Império do Brasil no século XIX. O autor das palavras que nos servem de epígrafe foi advogado, jornalista, banqueiro, ministro da Fazenda e conselheiro de Estado, eleito uma vez deputado provincial, cinco vezes deputado geral e, por fim, senador vitalício do Império pelo Partido Conservador até a Proclamação da República, em 15 de novembro de 1889. Era um homem umbilicalmente vinculado ao estado de coisas reinante, que atribuía à grande participação popular e não aos seus pares a responsabilidade pelos vícios do sistema representativo de seu tempo. Em sua opinião, o fim das fraudes eleitorais passava pela exclusão da maior parte de seus compatriotas, tidos como incapazes do ponto de vista material, intelectual, político e moral. Para ele, só uma parte do povo - aquela que fosse proprietária e escolarizada - estava

1 SOUZA, Francisco Belisário Soares de. O sistema eleitoral no Império (com apêndice contendo a legislação eleitoral no período 1821-1889). Brasília: Senado Federal, 1979, p.36 e p.131. Os interessados em obter dados biográficos do autor devem consultar: LYRA, Tavares de. Instituições políticas do Império. Brasília: Senado Federal/UnB, 1979, p.253-254. 
apta a valorizar e sustentar a cidadania política, no que estava em sintonia perfeita com o pensamento das elites políticas e econômicas do ocidente.

Francisco Belisário Soares de Souza e a maior parte de seus patrícios tinham não apenas origens e condições sociais radicalmente diferentes, mas compreensões igualmente distintas sobre o que era a cidadania, quem tinha direito a tê-la, os limites que deveriam ser impostos a cada indivíduo e o papel de cada um na sociedade e na política. Em alguma medida, o que ele pensava e dizia era representativo daquilo que estava nas cabeças e nas palavras dos membros das classes dominantes, que se aproximavam, cada vez mais, do ideal de restrição dos direitos políticos e de diminuição do eleitorado do país.

\section{Os limites da cidadania}

Em sua obra clássica, T. H. Marshall definiu a cidadania enquanto o conjunto dos direitos civis, políticos e sociais, historicamente conquistados pelos indivíduos de uma nação. Os direitos civis compreendiam o conjunto das liberdades individuais: liberdade de locomoção, de imprensa, de pensamento e credo, além do direito de propriedade privada e a igualdade jurídica; os direitos políticos diziam respeito à participação direta ou indireta dos negócios públicos do país; e os direitos sociais ligavam-se ao bem-estar econômico assegurado pelo sistema educacional e os serviços sociais. ${ }^{2}$

Essa definição de cidadania colocou um grande problema para a realização de certos estudos, já que a sequência histórica observada por Marshall para a Inglaterra não serve como modelo explicativo para os demais países, particularmente para as sociedades escravistas, como o Império do Brasil no século XIX. Já se observou que a realidade brasileira foi de grande complexidade, tendo assimilado criticamente elementos da experiência europeia e estadunidense, resultando em uma superposição de demandas por direitos, principalmente após a Proclamação da República. ${ }^{3}$

Além disso, a historiografia tem se debruçado sobre a participação direta dos cidadãos no Poder Judiciário na qualidade de juiz de paz ou jurado na justiça criminal e cível. ${ }^{4}$ Para além das instituições e rituais clássicos da

2 MARSHALL, T. H. Cidadania, classe social e status. Rio de Janeiro: Zahar Editores, 1967, p.63-74.

3 GOMES, Ângela de Castro. Cidadania e direitos do trabalho. Rio de Janeiro: Jorge Zahar Editor, 2002, p.10-12; CARVALHO, José Murilo de. Cidadania no Brasil: o longo caminho. Rio de Janeiro: Civilização Brasileira, 2001, p.7-13.

4 Para um estudo clássico sobre a Justiça de Paz no Império, cf. FLORY, Thomas. Judge and jury imperial Brazil, 1808-1871: social control and political stability in the new state. Austin: University of Texas Press, 1981. Para uma pesquisa recente centrada no caso capixaba, cf. CAMPOS, Adriana Pereira; BETZEL, Viviani Dal Piero. Júri no Brasil Império: polêmicas e desafios. In: RIBEIRO, Gladys Sabina. (org.). Brasileiros e cidadãos: modernidade política (1822-1930). São Paulo: Alameda, 2008, p.227-256; CAMPOS, Adriana Pereira. Justiça e participação política no Brasil do oitocentos: diálogos cruzados entre a História e o Direito. In: CAMPOS, Adriana Pereira; GIL, Antonio Carlos Amado; SILVA, Gilvan Ventura da; BENTIVOGLIO, Julio Cesar; NADER, Maria Beatriz. (orgs.). Territórios, poderes, identidades: a ocupação do espaço entre a política e a cultura. Vitória/Paris/Braga: GM Editora/Université de Paris-Est/Universidade do Minho, 2012, p.167-189. 
democracia, como o congresso, os partidos e as eleições, o conceito de cidadania foi significativamente alargado de modo a estudar o envolvimento dos indivíduos com a imprensa, a literatura, o teatro e o samba em suas relações com o Estado, a Polícia, a Guarda Nacional, o Exército e a Marinha. ${ }^{5}$

O envolvimento da classe trabalhadora com a política no Brasil Império visando assegurar melhor colocação no mercado de trabalho para os brasileiros foi o objeto do cuidadoso estudo feito por Marcelo Mac Cord para a cidade do Recife. Por meio da análise da atuação de duas irmandades religiosas e uma associação de auxílio mútuo, o autor conseguiu reconstituir as estratégias de sobrevivência e ascensão social de artífices livres e libertos, pretos e pardos, na capital pernambucana no século XIX. Ganha destaque o esforço empreendido pelos artesãos, inclusive em suas alianças eleitorais, para serem reconhecidos enquanto operários dotados de qualificação superior e orgulho profissional, merecedores, por isso, de distinção social. ${ }^{6}$

Nosso estudo também tem como objetivo a análise das tramas que envolviam os trabalhadores com a grande política no Brasil imperial. Contudo, em lugar de estudar os artesãos vinculados a certas entidades religiosas e mutualistas, como fez Mac Cord para o Recife, optamos por proceder a uma apreciação mais geral sobre a inserção das várias frações da classe trabalhadora de Salvador com os pleitos eleitorais da segunda metade do século XIX. Para uma melhor compreensão desse processo, é preciso conhecer quais eram os limites impostos ao exercício da cidadania.

A Constituição Política do Império do Brasil, outorgada em 25 de março de 1824 , em seu Título $2^{\circ}$, Art. $6^{\circ}$, considerava cidadãos todos os indivíduos que tivessem nascido no Brasil, inclusive os libertos, ainda que o pai fosse estrangeiro, desde quando não estivesse a serviço de outro Estado Nacional. Logo, não havia barreiras formais de "cor" ou "raça" para a aquisição de cidadania. As pessoas nascidas em Portugal ou em quaisquer de suas possessões, mas que morassem no Brasil à época em que foi Proclamada a Independência, em 7 de setembro de 1822, e não houvessem expressado o desejo de manter a nacionalidade portuguesa, foram consideradas cidadãs brasileiras automaticamente. ${ }^{7}$

5 CARVALHO, José Murilo de (org.). Nação e cidadania no Império: novos horizontes. Rio de Janeiro: Civilização Brasileira, 2007; CARVALHO, José Murilo de; NEVES, Lúcia Maria Bastos Pereira das (orgs.). Repensando o Brasil do oitocentos: cidadania, política e liberdade. Rio de Janeiro: Civilização Brasileira, 2009.

6 MAC CORD, Marcelo. Andaimes, casacas, tijolos e livros: uma associação de artífices no Recife, 1836-1880. Campinas: Universidade Estadual de Campinas, 2009 (História, Tese de doutorado).

7 CONSTITUIÇÃO POLITICA DO IMPÉRIO DO BRASIL - Jurada a 25 de março de 1824. In: Constituições do Brasil. Compilação dos textos, notas, revisão e índices: Adriano Campanhole e Hilton Lobo Campanhole. 5 ed. São Paulo: Atlas, 1981, p.629-651. 
No Capítulo Vl, Artigos 90 a 97 da Constituição de 1824, estabeleciamse as inclusões e exclusões no que diz respeito ao direito de tomar parte nas eleições, fosse como votante, eleitor ou candidato. Assegurava-se o direito de voto, nas eleições primárias, a todos os cidadãos brasileiros ou estrangeiros naturalizados do sexo masculino a partir dos 25 anos. Se eles fossem casados, ou detentores de patentes de oficiais militares, adquiririam seus direitos políticos a partir dos 21 anos, o mesmo valendo para os "clérigos de ordens sacras" e os "bacharéis formados". Estavam excluídos dos direitos políticos os "religiosos" e as pessoas que vivessem em "comunidade claustral", os "filhos famílias", isto é, os adultos que ainda estavam na companhia e/ou sob a tutela de seus pais (exceção feita aos que servissem em "ofícios públicos") e os "criados de servir" (grupo em que não deveriam ser incluídos os "guarda-livros" e os "primeiros caixeiros" das casas comerciais, os "criados da Casa Imperial" que não fossem de "galão branco" e os administradores de "fazendas rurais" e "fábricas").

Até 1881, as eleições eram indiretas, isto é, em dois turnos, ou graus, para usarmos a linguagem da época, uma clara inspiração na Constituição francesa de $1791 .{ }^{8}$ Os cidadãos ativos eram de duas ordens: votantes e eleitores. Ambos tinham que se enquadrar em uma das condições acima mencionadas para conseguirem se alistar. No primeiro turno, os votantes sufragavam os candidatos a eleitores, e estes elegiam, no segundo turno, os representantes do povo nas Assembleias Provinciais e na Câmara dos Deputados. Os eleitores escolhiam, ainda, os membros do Senado sempre que houvesse vacância em uma de suas cadeiras. ${ }^{9}$ A Justiça de Paz também era eletiva, com seus integrantes sendo eleitos pelo voto direto, o mesmo ocorrendo com os vereadores, que acumulavam funções legislativas e executivas no plano local. ${ }^{10} \mathrm{O}$ poder executivo no plano provincial era exercido pelos presidentes de província, nomeados pelo imperador.

8 A Constituição francesa de 1791 dividiu os portadores de direitos políticos em três categorias: os cidadãos passivos, setor formado por três milhões de indivíduos excluídos dos direitos eleitorais em função de não disporem de propriedades; os cidadãos ativos, grupo formado por cerca de quatro milhões de pessoas, pagadores de contribuição direta equivalente a três dias de trabalho, que se reuniam em assembleias primárias para designar as municipalidades e os eleitores; e os eleitores propriamente ditos, minoria formada por cinquenta mil franceses escolhidos à razão de um para cada cem cidadãos ativos. Os sujeitos que formavam esse grupo contribuíam com o equivalente a dez dias de trabalho, e reuniam-se em assembleias eleitorais, nas capitais dos departamentos, para designar os deputados, juízes e membros das administrações departamentais. Por fim, os deputados que integravam a assembleia legislativa deveriam ser detentores de propriedades de raiz e pagar uma contribuição de um marco de prata. Sobre o assunto, cf. SOBOUL, Albert. A Revolução Francesa. Lisboa: Livros Horizonte, 1979, v.1, p.144-145.

9 O Senado era vitalício. Quando surgia uma vaga, procedia-se à eleição e os três nomes mais votados eram encaminhados ao Imperador, que mandava diplomar um de sua livre escolha.

10 Até 1875, os juízes de paz cumpriam um papel central nas eleições, especialmente nas juntas de qualificação quando se decidia quem poderia ou não se alistar como votante, e nas próprias mesas receptoras de votos. Um decreto de 4 de maio de 1842 criou o procedimento da qualificação prévia dos votantes e dos elegíveis, tarefa que ficava a cargo de uma junta composta do juiz de paz, do vigário e do delegado ou subdelegado de polícia. Já a Lei 383, de 19 de agosto de 1846, reorganizou essa junta qualificadora, que passou a ser composta pelo juiz de paz mais votado, investido como seu presidente e personagem determinante na definição da maioria, e mais outros quatro membros, encarregados das funções de mesários, secretários e escrutinadores, escolhidos 
O voto era censitário, exigindo-se dos votantes uma renda anual de cem mil-réis, e dos eleitores, de duzentos mil-réis. Com a reforma eleitoral de 1846, esses valores foram duplicados, mas, como veremos, eles não eram suficientemente elevados a ponto de impedir a qualificação de pessoas relativamente pobres que aspirassem direitos de cidadania. Além disso, tais rendas poderiam ser apenas declaradas, dispensando-se ou sendo flexível sua comprovação. Como demonstraremos mais adiante, até 1881, as listas de votantes estão repletas de membros das classes operárias em geral e dos trabalhadores de ofício em particular, mais qualificados e melhor remunerados.

Além das questões relativas à inclusão ou exclusão nas definições dos direitos políticos, é importante apontar, também, alguns elementos do funcionamento do próprio sistema político-eleitoral. Sob o Império, o Poder Moderador, exercido pelo Imperador, era o centro de onde emanavam as principais decisões, pois, na singular experiência da monarquia constitucional brasileira, a ele competia dissolver ou convocar o Parlamento por meio de novas eleições, demitir ou admitir Gabinetes, independente de maiorias ou minorias políticas do Partido Conservador ou do Partido Liberal, chamados ao comando do Governo de acordo com a vontade e a conveniência do monarca. Como constatou Raymundo Faoro, esse poder de compor ou depor Gabinetes sem que eles tivessem, necessariamente, maioria na Câmara dos Deputados, era legal, posto que constitucional, mas ilegítimo, do ponto de vista da doutrina inglesa. Daí que para esse autor o regime existente no Brasil era uma farsa, na qual o imperador reinava, governava e administrava. As câmaras eram produtos dos gabinetes, o oposto do que prescrevia o credo liberal, que mandava fazer, primeiro, as eleições, quando seria eleito o partido com maioria no parlamento, saindo dele o primeiro-ministro. ${ }^{11}$

Outra questão importante diz respeito à circunscrição eleitoral. Até 1855, os deputados eram eleitos por maioria simples, tendo como referência a província. O Decreto no 842, de 19 de setembro de 1855, conhecido como Lei dos Círculos, alterou esse quadro, introduzindo no país o voto distrital, por meio do qual cada deputado, para ser eleito, deveria obter maioria absoluta dos votos de sua circunscrição. O objetivo declarado era o de assegurar às minorias o direito de representação na Câmara dos Deputados, um discurso que passou a ser recorrente. Além disso, com o objetivo de diminuir a influência do governo nas eleições, a lei de 1855 criou uma série de incompatibilidades, ou seja, vetou a um grande número de funcionários

entre os eleitores das facções envolvidas na disputa. Cf. SOUZA, Francisco Belisário Soares de Souza. O sistema eleitoral no Império, p.26-27.

11 FAORO, Raymundo. Os donos do poder: formação do patronato político brasileiro. 3 ed. revista. São Paulo: Globo, 2001, p.410-411. 
comissionados e autoridades policiais, judiciárias e administrativas o direito de se candidatarem para que não fizessem uso da máquina administrativa em proveito próprio.

Contudo, alegando que o novo sistema havia dado lugar ao predomínio do poder local e ao enfraquecimento dos partidos políticos e da unidade nacional, as elites trocaram esse dispositivo por outro. O Decreto 1.082, de 18 de agosto de 1860, substituiu os círculos de um deputado pelos círculos de três deputados, por meio dos quais os três candidatos mais votados em cada distrito seriam eleitos por maioria simples. Não demorou até que, em 20 de outubro de 1875, esse sistema também fosse revogado pelo Decreto 2.675, conhecido como Lei do Terço, que suprimiu o voto distrital e colocou em seu lugar a antiga representação por circunscrição provincial. A novidade era que agora o eleitor votava em apenas dois terços dos cargos disponíveis, e não na chapa completa. O Decreto 3.029, de 9 de janeiro de 1881, mais conhecido como Lei Saraiva, restabeleceu os distritos de um deputado para a eleição de representantes à Assembleia Geral, e fixou a renda mínima exigida para se alistar um eleitor em duzentos mil-réis. Apontou-se para a necessidade de se garantir o sigilo do voto e foram ampliados os casos de inelegibilidade e incompatibilidade. ${ }^{12}$

Apesar de não ter sido stricto sensu universal, o direito de voto se mostrou relativamente alargado. De fato, a Constituição de 1824 definiu os libertos nascidos no Brasil como cidadãos, assegurando-lhes o direito de serem votantes nas eleições de primeiro turno. Porém, além da constante vigilância a que estavam submetidos, dos riscos de reescravização e das inúmeras e diversificadas limitações a sua mobilidade sócio-econômica e espacial, o Art. 93 da Constituição Imperial vetava a plenitude da cidadania política dos ex-escravos, excluindo-os da condição de elegíveis ou mesmo de eleitores de segundo grau..$^{13}$ Os escravos, obviamente, estavam terminantemente excluídos do direito de voto, já que não eram cidadãos, e as mulheres, apesar de serem cidadãs do ponto de vista dos direitos civis, na prática continuaram excluídas de direitos políticos.

12 SOUZA, O sistema eleitoral no Império; PORTO, Walter Costa. O voto no Brasil: da Colônia à 6a República. $2^{\mathrm{a}}$ ed rev., Rio de Janeiro: Topbooks, 2002, p.186.

13 Para uma análise mais detida sobre a precariedade da liberdade e as restrições à cidadania dos libertos, cf. CHALHOUB, Sidney. Visões da liberdade: uma história das últimas décadas da escravidão na corte. São Paulo: Companhia das Letras, 1990; CHALHOUB, Sidney. Machado de Assis, historiador. São Paulo: Companhia das Letras, 2003; GRINBERG, Keila. Reescravização, direitos e justiças no Brasil do século XIX. In: LARA, Silvia Hunold; MENDONÇA, Joseli Maria Nunes. (orgs.). Direitos e justiças no Brasil: ensaios de história social. Campinas: Editora da Unicamp, 2006, p.101-128; MATTOS, Hebe Maria. Racialização e cidadania no Império do Brasil. In: CARVALHO, José Murilo de. (org.). Repensando o Brasil do Oitocentos: cidadania, política e liberdade. Rio de Janeiro: Civilização Brasileira, 2009, p.349-391; LUNA, Francisco Vidal; KLEIN, Herbert S. Escravismo no Brasil. São Paulo: Edusp/Imprensa Oficial do Estado de São Paulo, 2010, p.271-315; MENDONÇA, Joseli Nunes. Cenas da abolição: escravos e senhores no Parlamento e na Justiça. São Paulo: Fundação Perseu Abramo, 2001; REIS, João José. Domingos Sodré, um sacerdote africano. São Paulo: Companhia das Letras, 2008; REIS, João José; GOMES, Flávio dos Santos; CARVALHO, Marcus J. M. de. O Alufá Rufino: tráfico, escravidão e liberdade no Atlântico negro (c.1822-c.1853). São Paulo: Companhia das Letras, 2010. 
No que diz respeito às barreiras levantadas contra a cidadania plena dos ex-cativos, Joaquim Nabuco observou, em seu clássico O abolicionismo, de 1883, que os libertos só adquiriram o direito de elegibilidade após a reforma de 1881, quando foi suprimida a eleição indireta, em dois turnos. ${ }^{14}$ De fato, Richard Graham sustentou que, inicialmente, o baiano José Antonio Saraiva (1823-1895), líder do Gabinete Liberal, havia concebido a lei de 1881 com referências explícitas à mudança de status dos libertos, assegurando-lhes a condição de eleitores e elegíveis, embora fosse patente seu objetivo de redução do número dos que podiam votar no país. De todo modo, os protestos de seus pares fizeram-no recuar da menção direta aos libertos, mas a lei foi aprovada com uma redação que garantia tais direitos aos ex-cativos, desde que eles preenchessem os outros requisitos exigidos dos demais cidadãos, como renda comprovada e escolarização. ${ }^{15}$

As exclusões de direitos políticos brasileiros não eram anomalias. Elas estavam em profunda sintonia com o entendimento e as variadas restrições à cidadania praticadas na Europa do período. Eric Hobsbawm observou que as reformas de 1867 e 1883 na Inglaterra aumentaram o eleitorado masculino maior de 21 anos de 8\% para 29\% da população, mas o clientelismo, a manipulação e as fraudes eram práticas inseparáveis das eleições e se constituíam em sérios entraves à participação popular. No pleito de 1914, metade da classe operária foi impedida, na prática, de votar, graças às múltiplas dificuldades criadas durante o alistamento eleitoral. ${ }^{16}$

Do ponto de vista da barreira de sexo, vale dizer que o Decreto de 5 de março de 1848, instituindo o voto universal na França, na realidade suprimiu a exigência de renda, isto é, derrubou a barreira socioeconômica, mas manteve a exclusão feminina, já que a lei garantia o direito de voto aos homens maiores de 21 anos e o direito de elegibilidade aos maiores de 25 anos. ${ }^{17}$

Foi a Nova Zelândia o primeiro país a conceder o direito de voto às mulheres (1893). A Alemanha assegurou tal direito feminino em 1918, enquanto Áustria e Holanda o fizeram em 1919. As mulheres do Reino Unido do inglês livre de nascimento só garantiram o direito ao sufrágio em 1928, após uma vigorosa campanha e sérios enfrentamentos com as forças policiais. Na França da Declaração dos Direitos do Homem e do Cidadão o voto feminino só foi instituído em 1944, doze anos depois do Brasil, que aprovou tal direito com o Código Eleitoral de 1932. ${ }^{18}$

14 NABUCO, Joaquim. O abolicionismo. Rio de Janeiro: Nova Fronteira, 1999, p.25.

15 GRAHAM, Richard. Clientelismo e política no Brasil do século XIX. Rio de Janeiro: Editora UFRJ, 1997, p.261.

16 HOBSBAWM, Eric J. A era dos impérios (1875-1914). 2 ed. Rio de Janeiro: Paz e Terra, 1989, especialmente o Capítulo 4 - A política da democracia. As citações são das páginas 127 e 129.

17 GARRIGOU, Alain. O rascunho do sufrágio universal: arqueologia do Decreto de 5 de março de 1848. In: CANÊDO, Letícia Bicalho. (org.). O sufrágio universal e a invenção democrática. São Paulo: Estação Liberdade, 2005, p.37-63.

18 NICOLAU, Jairo. A participação eleitoral no Brasil. In: VIANNA, Luiz Werneck. (org.). A democracia e os três poderes no Brasil. Belo Horizonte/Rio de Janeiro: Editora da UFMG/IUPERJ/FAPERJ, 2003, p.255-295. Para o rico material fotográfico produzido ao longo da campanha pelo sufrágio feminino na Inglaterra, além da biografia das 


\section{O exercício da cidadania}

Apesar dos limites formais ao envolvimento popular nas eleições, os trabalhadores tomaram parte ativa na política do Império do Brasil por todo o século XIX. Em um dos primeiros trabalhos de pesquisa feitos com base nas listas eleitorais, Maria Yedda Linhares calculou em 24,6\% o total de trabalhadores urbanos e artesãos qualificados para o voto na cidade do Rio de Janeiro em 1876. Naquele ano, a então Corte Imperial tinha 15.958 votantes alistados em suas 21 freguesias (oito rurais e treze urbanas), e sua população foi estimada em 235.381 habitantes no ano de 1870, sendo que $50.092(21,28 \%)$ eram escravos e 64.917 (27,57\%) eram estrangeiros. Cruzando os números da população da cidade com o de cidadãos qualificados, chegou-se ao percentual aproximado de $6,8 \%$ de votantes potenciais. ${ }^{19}$

Outro exemplo pode ser retirado de uma pesquisa sobre Campos dos Goytacazes, na então província do Rio de Janeiro, feita com base nas listas eleitorais de três paróquias daquela cidade: São Salvador (1876), São Gonçalo (1878) e N. S. da Natividade do Carangola (1878). O número de votantes achado foi de $2.508,2,8 \%$ da população total de 88.825 habitantes. Na freguesia de São Salvador, que era urbana, 53\% dos qualificados eram artesãos ou estavam vinculados ao comércio ou serviços, ao passo que nas freguesias de São Gonçalo e N. S. da Natividade do Carangola, ambas rurais, $75 \%$ dos alistados estavam ocupados na agricultura, pecuária, atividades extrativas ou eram lavradores. ${ }^{20}$

Nosso estudo também recorreu às fontes eleitorais, combinando-as analiticamente com as informações do Recenseamento Geral de $1872,{ }^{21}$ da imprensa coetânea e do banco de dados que montamos sobre artesãos nascidos no século XIX.22 Isso nos permitiu calcular os percentuais de participação política dos cidadãos soteropolitanos nas eleições de Salvador, dando-se especial atenção ao peso do voto operário. Até 1871, Salvador ainda conservava as circunscrições trazidas do século XVIII, sendo formada por dez freguesias urbanas e sete rurais. Nesse ano, foi criada a freguesia urbana dos Mares, surgida do desmembramento das paróquias do Pilar e

inúmeras mulheres ativistas envolvidas, cf. ATKINSON, Diane. The suffragetts in pictures. Londres: The History Press/Museum of London, 2010.

19 LINHARES, Maria Yedda Leite. As listas eleitorais do Rio de Janeiro no século XIX: projeto de classificação profissional. Revista Brasileira de Estudos Políticos, Belo Horizonte, v.48, p.121-153, 1979.

20 NUNES, Neila Ferraz Moreira. A experiência eleitoral em Campos dos Goytacazes (1870-1889): freqüência eleitoral e perfil da população votante. Dados - Revista de Ciências Sociais, Rio de Janeiro, v.46, n.2, p.311-343, 2003.

21 Recenseamento Geral do Brazil em 1872 - Bahia. Disponível em: <http://biblioteca.ibge.gov.br/>. Acesso em: 01 out. 2007.

22 Parte das informações desse banco de dados foi analisada em CASTELLUCCI, Aldrin A. S. Classe e cor na formação do Centro Operário da Bahia (1890-1930). Afro-Asia, Salvador, n.41, p.85-131, 2010. 
de Santo Antonio. A partir de então, Salvador passou a ter dezoito paróquias, onze urbanas e sete rurais. ${ }^{23}$

Localizamos no Arquivo Histórico de Salvador (AHS-FGM) e no Arquivo Público do Estado da Bahia (APEB) listas de votantes para quase todas as freguesias urbanas e suburbanas de Salvador. Das onze paróquias urbanas, encontramos listas para dez delas: Sé (1876), São Pedro (1876), Santana (1876), Vitória (1880), Conceição da Praia (1876), Pilar (1859), Mares (1874), Santo Antonio (1853), Penha (1875) e Brotas (1879). A lista da Rua do Paço (1876) foi acessada na versão publicada pelo Correio da Bahia do século XIX. Das sete freguesias suburbanas, conseguimos listagens de votantes para cinco delas: Ilha de Maré (1865), Matoim (1870), Itapuã (1880), Passé (1880) e Paripe (1858). Em que pese nossos esforços, não nos foi possível acessar as listas para as paróquias de Pirajá e Cotegipe. Por fim, não conseguimos reunir listas que compusessem uma série completa para os mesmos anos de qualificação em todas as freguesias, como fez Linhares e Klein ${ }^{24}$ para o Rio de Janeiro e São Paulo. Este fato nos levou a estabelecer como critério de análise o uso de listas posteriores a 1850 e anteriores a 1881, ano da Lei Saraiva e todo o seu corolário de restrições aos direitos políticos dos pobres e dos trabalhadores.

Essas fontes continham centenas de nomes em grandes folhas avulsas ou em livros, ao lado dos quais eram anotados importantes dados acerca da idade, naturalidade, profissão/ocupação, escolaridade, filiação, domicílio e renda dos cidadãos qualificados como votantes e sua condição de elegíveis ou não. Adicionalmente, conseguimos as listas dos eleitores para todos os distritos eleitorais da Bahia, o que nos permitiu mensurar a quantidade de indivíduos que detinham a plenitude dos direitos políticos em relação aos votantes das eleições primárias do Império. ${ }^{25}$

23 MATTOSO, Katia M. de Queirós. Bahia, século XIX: uma província no Império. 2 ed. Rio de Janeiro: Nova Fronteira, 1992, p.100-104, p.435.

24 KLEIN, Herbert S. A participação política no Brasil do século XIX: os votantes de São Paulo em 1880. Dados Revista de Ciências Sociais, Rio de Janeiro, v.38, n.3, 1995

25 Almanak administrativo, commmercial e industrial da província da Bahia para o anno de 1873, qüinquagésimo segundo da Independência e do Império. Compilado por Albino Rodrigues Pimenta, Bacharel em Direito e Chefe de Seção da Secretaria da Presidência. Anno I. Bahia: Typographia de Oliveira Mendes \& C., 1872. 
Tabela 1

Número de votantes de Salvador por freguesia (1850-1881)

\begin{tabular}{|c|c|c|c|c|}
\hline FREGUESIAS URBANAS & 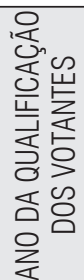 & 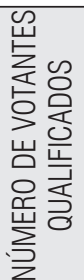 & 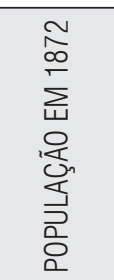 & 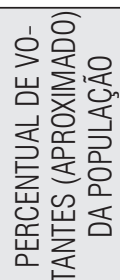 \\
\hline SÃO SALVADOR DA SÉ & 1876 & 359 & 15.111 & 2,4 \\
\hline SÃO PEDRO VELHO & 1876 & 1.284 & 14.743 & 8,7 \\
\hline SANTISSIMO SACRAMENTO DE SANTANA & 1876 & 191 & 17.954 & 1,1 \\
\hline NOSSA SENHORA DA VITORIA & 1880 & 686 & 11.666 & 5,9 \\
\hline NOSSA SENHORA DA CONCEICÂO DA PRAIA & 1876 & 454 & 5.490 & 8,3 \\
\hline SANTISSIMO SACRAMENTO DO PILAR & 1859 & 997 & 8.346 & 11,9 \\
\hline SANTISSIMO SACRAMENTO DA RUA DO PACO & 1876 & 360 & 3.636 & 9,9 \\
\hline NOSSA SENHORA DOS MARES & 1874 & 90 & 3.722 & 2,4 \\
\hline SANTO ANTONIO ALEM DO CARMO (10 e $2^{\circ}$ DISTRITOS) & 1853 & 830 & 16.613 & 5,0 \\
\hline NOSSA SENHORA DA PENHA DE ITAPAGIPE & 1875 & 576 & 5.767 & 10,0 \\
\hline NOSSA SENHORA DE BROTAS & 1879 & 769 & 5.090 & 15,1 \\
\hline SUBTOTAL & - & 6.596 & 108.138 & 6,1 \\
\hline FREGUESIAS SUBURBANAS & 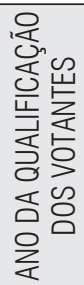 & 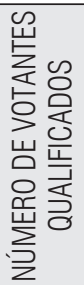 & 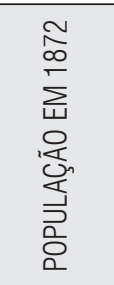 & 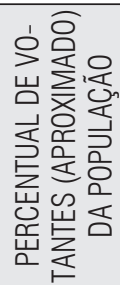 \\
\hline SÃO BARTOLOMEU DE PIRAJÁ & - & - & 2.863 & - \\
\hline SANTANA DA ILHA DE MARE & 1865 & 200 & 1.124 & 17,8 \\
\hline NOSSA SENHORA DA PIEDADE DE MATOIM & 1870 & 191 & 2.446 & 7,8 \\
\hline NOSSA SENHORA DA COCEICÂO DE ITAPUÂ ( $1^{\circ}$ e $2^{\circ}$ DISTRITOS) & 1880 & 788 & 4.935 & 16,0 \\
\hline SÃO MIGUEL DE COTEGIPE & - & - & 2.052 & - \\
\hline NOSSA SENHORA DA ENCARNACCÃO DE PASSÉ & 1880 & 643 & 4.443 & 14,5 \\
\hline NOSSA SENHORA DO OO DE PARIPE & 1858 & 274 & 8.108 & 3,4 \\
\hline SUBTOTAL & - & 2.096 & 25.971 & 8,1 \\
\hline TOTAL & - & 8.692 & 134.109 & 6,5 \\
\hline
\end{tabular}

Fontes: FGM-AHS. Setor de Arquivos Permanentes - Fundo: Eleitoral - Séries Documentais - Listas Eleitorais 1828-1893 (Paróquia de Nossa Senhora da Conceição da Praia - 1876; Paróquia de Itapuã - 1880; Paróquia de Santana - 1876; Paróquia da Sé - 1876; Paróquia de São Pedro - 1876); Livro 116 - Listas Gerais de Votantes da Paróquia de Brotas - 1879; Livro 592 - Qualificação da Freguesia da Penha de Itapagipe - 18591875; Livro 619 - Junta de Qualificação dos Votantes da Freguesia da Vitória - 1880; Livro 620 - Qualificação da Freguesia do Passé - 1880; APEB, Seção de Arquivos Coloniais e Provinciais, $1^{\text {a }}$ Parte - Série Justiça Correspondência Recebida da Junta de Qualificação, maço 2830 - Qualificação da Freguesia de Santana da llha de Maré - 1865; maço 2830 - Qualificação da Freguesia de N. S. do Matoim - 1870; maço 2814 - Qualificação da Freguesia do Pilar - 1859; maço 2830.1 - Qualificação da Freguesia dos Mares - 1874; maço 2807 - Qualificação da Freguesia de Santo Antonio Além do Carmo - 1853; Lista geral de qualificação dos cidadãos aptos para votarem e serem votados na Paróquia da Rua do Paço, organizada pela Junta Municipal da Capital da Bahia, em virtude do Decreto 2.675 de 20 de outubro de 1875 e instruções regulamentares de 12 de janeiro de 1876. Correio da Bahia, Salvador, 12 a 14 dez. 1876, p. 2 e 3 . Recenseamento Geral do Brazil em 1872 - Bahia. Disponível em: <http://biblioteca.ibge.gov.br/>. Acesso em: 01 out. 2007. 
A primeira observação a ser feita a partir da análise da Tabela 1 é que o número de indivíduos habilitados ao exercício dos direitos políticos nas eleições primárias foi de 8.692 votantes, ou seja, 6,5\% dos 134.109 habitantes de Salvador segundo os dados do Recenseamento Geral de 1872. Esse percentual está abaixo da média nacional do Império até 1881. Pelos cálculos de José Murilo de Carvalho, 1.097.698 de indivíduos estavam aptos a votar nas eleições primárias em 1872, 10,8\% da população do Brasil naquele ano. Excluídos os escravos, esse percentual poderia chegar a 13\%. Em 1886, cinco anos depois de a Lei Saraiva ter sido aprovada, o número de cidadãos que poderiam se qualificar eleitores era de 117.022, isto é, $0,8 \%$ da população. ${ }^{26}$

Já Sérgio Buarque de Holanda nos informou que a população de votantes do Brasil em 1874 era de 1.114.066 indivíduos. Depois de 1881, os eleitores passaram a ser de 145.296, menos de 1,5\% da população brasileira, estimada em 9.941.471. ${ }^{27}$ As estimativas de Richard Graham apontam para a mesma direção. Em 1870, o número de cidadãos que dispunham dos requisitos para serem votantes era de 1.039.659, ao passo que, depois de 1881, o Brasil passou a ter cerca de 150 mil indivíduos qualificados ao exercício da condição de eleitores, dos quais apenas 96.411 efetivamente votaram naquele ano. ${ }^{28}$

Contudo, os números achados para Salvador são muito próximos dos algarismos encontrados para outras cidades da época, a exemplo do Rio de Janeiro (6,8\%) e de São Paulo (6,5\%). ${ }^{29}$ Essa defasagem entre o percentual global e o encontrado para as cidades parece indicar que os potentados rurais foram mais eficientes do que os chefes políticos urbanos na tarefa de arregimentar legiões de votantes e colocá-los a seu serviço. A hipótese ganha força quando analisamos comparativamente as informações sobre as áreas urbanas e rurais de Salvador. O primeiro aspecto que chama atenção nessa análise é o fato de os indivíduos residentes na área urbana constituírem um conjunto quatro vezes maior que o da rural. O mesmo raciocínio vale para a quantidade de cidadãos alistados na cidade, pois na zona urbana esse número era três vezes maior que na suburbana.

Em termos absolutos, portanto, havia uma quantidade maior de habitantes e de detentores de direitos políticos nas paróquias urbanas que nas rurais. Contudo, em termos relativos, a situação era bem diferente. Verificamos que o percentual médio de qualificados ao voto nas paróquias

26 CARVALHO, José Murilo de. A construção da ordem: a elite política imperial. Teatro de sombras: a política imperial. Rio de Janeiro: Civilização Brasileira, 2003, p.395.

27 HOLANDA, Sérgio Buarque de. História geral da civilização brasileira, t.Il (O Brasil Monárquico), v.7 - (Do Império à República). 7 ed. Rio de Janeiro: Bertrand Brasil, 2005, p.262-263.

28 GRAHAM, Richard. Clientelismo e política no Brasil do século XIX. Rio de Janeiro: Editora UFRJ, 1997, p.262 e p.464-465.

29 Para o Rio de Janeiro, cf. o já citado estudo de Linhares. Para São Paulo, cf. KLEIN, Herbert S. A participação política no Brasil do século XIX, p.527-544. 
urbanas de Salvador era de 6,1\%, 6.596 de seus 108.138 residentes. Já nas freguesias rurais da capital baiana, os 2.096 votantes alistados correspondiam a 8,1\% de seus 25.971 moradores. Como não conseguimos localizar listas eleitorais para Pirajá e Cotegipe, é certo que esse percentual era ainda maior, podendo ficar próximo da média nacional de 10\%.

Além disso, os dois maiores índices de participação por freguesia estavam na llha de Maré, com impressionantes 17,8\%, e na distante paróquia de Itapuã, com 16\%, ambas rurais. Por outro lado, entre as paróquias classificadas como urbanas, a que tinha o maior percentual de cidadãos alistados era Brotas (15,1\%), que, como observou Kátia Mattoso, no século XIX era uma área semirrural, habitada por uma população majoritariamente branca, com limites que se estendiam até a Pituba. A Vitória era outra paróquia urbana com feição semirrural e limites que chegavam ao Rio Vermelho. Ela era habitada por parte das famílias brancas locais e estrangeiras pertencentes aos grupos e classes sociais dominantes da província. Em 1880, às vésperas da aprovação da Lei Saraiva, 5,9\% de seus habitantes estavam habilitados ao voto. ${ }^{30}$

O caso da paróquia da Sé é de compreensão difícil. Desde os tempos coloniais, essa área era o centro político e administrativo por excelência da urbe. Juntamente com as freguesias de São Pedro, Vitória e Paço, ela formava uma região privilegiada da Cidade Alta de Salvador, morada dos senhores de engenho, grandes comerciantes, banqueiros e industriais. Ali ficavam as melhores e mais suntuosas edificações, públicas ou privadas, laicas ou religiosas. A paróquia da Sé era uma das mais populosas e abastadas de Salvador. Contudo, fato surpreendente, possuía apenas 359 votantes registrados em 1876, o segundo menor índice percentual de cidadãos habilitados ao voto, isto é, 2,4\% de seus 15.111 moradores, ficando abaixo apenas de Santana (1,1\%). Era uma situação radicalmente diferente da verificada em São Pedro e no Paço, que naquele ano alistaram 8,7\% e 9,9\% de seus moradores, respectivamente.

Os números da Sé em 1876 estão visivelmente subestimados, fato que pode ser evidenciado com os dados referentes a períodos anteriores. Em 1862, portanto quatorze anos antes, o curato da Sé possuía nada menos que 1.329 votantes qualificados, $20,1 \%$ da população que aquela paróquia teria dez anos depois. Era o maior número de cidadãos habilitados ao voto em Salvador, tanto em termos absolutos quanto relativos. ${ }^{31}$

Igualmente intricada era a situação das freguesias da Cidade Baixa, onde estavam a estação ferroviária, o porto e suas importantíssimas atividades de importação e exportação, os trapiches, a Alfândega, as seguradoras,

30 MATTOSO, Kátia. Bahia, século XIX, p.103

31 APEB, Seção de Arquivos Coloniais e Provinciais, $1^{\text {a }}$ Parte - Série Justiça - Correspondência Recebida da Junta de Qualificação, maço 2808 - Qualificação do Curato da Sé. 
os bancos, o comércio atacadista e varejista, o barulhento comércio de rua, as companhias de navegação, o Arsenal de Guerra (com diversas oficinas que produziam fardamentos, armas e munições) e o Arsenal de Marinha (que tinha um estaleiro onde se fabricavam embarcações dos mais variados tipos). Essa região abrigava também centenas de oficinas, manufaturas, fábricas e fundições que empregavam milhares de artesãos e operários nos mais diversos ramos de produção.

Apesar das complexas relações que mantinham, havia diferenças entre as freguesias dessa região. As paróquias do Pilar, Penha e Mares tinham forte presença de escravos de ganho e trabalhadores negros e mestiços livres pobres. Mas enquanto as duas primeiras tinham, respectivamente, $11,9 \%$ e $10 \%$ de seus moradores registrados como votantes, a última possuía apenas 2,4\% de seus residentes dispondo de alguma cidadania. Já a Conceição da Praia, que era povoada por expressivo número de pessoas ricas e brancas, garantia o direito de voto a $8,3 \%$ de seus moradores.

Tabela 2

Número de votantes de Salvador por ocupação (1850-1881)

\begin{tabular}{c|c|c}
\hline PROFISSÃO / OCUPAÇÃO DOS & $\begin{array}{c}\text { NÚMERO DE CIDADÃOS } \\
\text { QUALIFICADOS }\end{array}$ & PERCENTUAL \\
\hline CIDADÃOS QUALIFICADOS & 6.304 & 72,5 \\
TRABALHADORES & 255 & 2,9 \\
PROFISSIONAIS LIBERAIS & 1.482 & 17,0 \\
NEGOCIANTES / COMERCIANTES & 226 & 2,6 \\
PROPRIETÁRIOS & 44 & 0,5 \\
SACERDOTES & 75 & 0,9 \\
POLICIAIS / MILITARES & 206 & 2,4 \\
OUTROS & 100 & 1,2 \\
NÃO IDENTIFICADOS & 8.692 & 100,0 \\
\hline TOTAL & & \\
\hline
\end{tabular}

Fontes: FGM-AHS. Setor de Arquivos Permanentes - Fundo: Eleitoral - Séries Documentais - Listas Eleitorais 1828-1893 (Paróquia de Nossa Senhora da Conceição da Praia - 1876; Paróquia de Itapuã - 1880; Paróquia de Santana - 1876; Paróquia da Sé - 1876; Paróquia de São Pedro - 1876); Livro 116 - Listas Gerais de Votantes da Paróquia de Brotas - 1879; Livro 592 - Qualificação da Freguesia da Penha de Itapagipe - 1859-1875; Livro 619 - Junta de Qualificação dos Votantes da Freguesia da Vitória - 1880; Livro 620 - Qualificação da Freguesia do Passé - 1880; APEB, Seção de Arquivos Coloniais e Provinciais, $1^{\text {a }}$ Parte - Série Justiça - Correspondência Recebida da Junta de Qualificação, maço 2830 - Qualificação da Freguesia de Santana da llha de Maré - 1865; maço 2830 - Qualificação da Freguesia de N. S. do Matoim - 1870; maço 2814 - Qualificação da Freguesia do Pilar - 1859; maço 2830.1 - Qualificação da Freguesia dos Mares - 1874; maço 2807 - Qualificação da Freguesia de Santo Antonio Além do Carmo - 1853; Lista geral de qualificação dos cidadãos aptos para votarem e serem votados na Paróquia da Rua do Paço, organizada pela Junta Municipal da Capital da Bahia, em virtude do Decreto 2.675 de 20 de outubro de 1875 e instruções regulamentares de 12 de janeiro de 1876. Correio da Bahia, Salvador, 12 a 14 dez. 1876, p. 2 e 3. 
Já demonstramos como o direito de voto, no Império, era relativamente alargado, ao menos nas eleições primárias até 1881. Contudo, precisamos marcar, especificamente, como era grande a participação das classes trabalhadoras, o que faremos por meio da análise da Tabela 2.

O número de trabalhadores alistados como votantes em Salvador era de 6.304 indivíduos, perfazendo expressivos 72,5\% dos 8.692 cidadãos qualificados. Dentro desse conjunto, 3.112 eram artesãos, correspondendo a $35,8 \%$ do total de alistados. No conjunto das classes trabalhadoras que dispunham de direitos políticos, destacamos, também, os 241 marítimos e os 268 saveiristas encontrados nas listas eleitorais, o que está em sintonia com o fato de Salvador ser uma cidade costeira e fortemente dependente das atividades econômicas ligadas ao porto e à navegação. Mas a capital baiana era um centro urbano que guardava, tanto em seu interior quanto em seu entorno, roças, hortas, chácaras e colônias de pesca, o que explica termos achado 1.256 votantes classificados como lavradores, roceiros e plantadores, e outros 687 listados como pescadores. Os empregados do setor privado, inclusive os do comércio, somavam 337 votantes, e os empregados públicos totalizavam 403 cidadãos alistados. As classes médias e dominantes estavam representadas, respectivamente, pelos 255 profissionais liberais e pelos 1.482 comerciantes e 226 proprietários alistados como votantes.

As várias categorias de trabalhadores votantes de Salvador estavam distribuídas de modo desigual pela cidade. Os operários e os artesãos qualificados estavam fortemente presentes em todas as freguesias de Salvador. Eles eram 593 (46,2\%) de São Pedro, $358(43,1 \%)$ de Santo Antonio, 210 (36,5\%) da Penha, 362 (36,3\%) do Pilar, 244 (35,6\%) da Vitória, 166 (46,2\%) da Sé, 167 (46,1\%) do Paço, 167 (36,8\%) da Conceição da Praia, 73 (38,2\%) de Santana e 38 (42,2\%) dos Mares. Mesmo em freguesias semirrurais e suburbanas os operários de ofício constituíam grande parte dos alistados, a exemplo de Brotas, Matoim e Paripe, com 276 (35,9\%) em 1879, 82 (42,9\%) em 1870 e 83 (35,9\%) em 1859, respectivamente.

Algumas categorias sócio-ocupacionais tinham presença mais significativa em determinadas paróquias que outras. Por razões óbvias, parte significativa dos trabalhadores do mar estava na Cidade Baixa. Na Conceição da Praia, os marítimos totalizavam 92 (20,3\%) votantes e os saveiristas 40 (8,8\%). No Pilar, nada menos que 172 votantes, 17,3\% dos cidadãos alistados, tiravam seu sustento da lide nos saveiros, e outros 75 (7,5\%) trabalhavam como marítimos. Igualmente compreensível é a forte presença dos empregados públicos na Cidade Alta. A freguesia de São Pedro abrigava 144 deles, expressivos 11,2\% do eleitorado de primeiro grau. Mas os funcionários públicos que votavam estavam espalhados por toda a cidade.

Nas paróquias suburbanas, os votantes eram, em sua maioria, trabalhadores engajados em atividades ligadas à agricultura, à criação e à pesca. 
É que muitas dessas áreas integravam regiões do Recôncavo dedicadas à lavoura do açúcar desde a época colonial, como Passé e Matoim, no atual município de Candeias, e Cotegipe, hoje cidade de Simões Filho. Nessas localidades estavam os engenhos maiores, mais antigos e mais bem situados, próximos de rios e da baía de Todos os Santos. Essas propriedades pertenciam a uma fração da classe dos senhores de engenho à qual Stuart Schwartz chamou de "tradicional aristocracia do açúcar", um grupo sem linhagens autênticas que aspirava ao status de nobreza, mas que não passava de uma "aristocracia de riqueza e poder". 32

Não foi sem razão que encontramos os nomes de vários proprietários, feitores e mestres de açúcar nas listas de votantes dessas freguesias. No Passé, a lavoura ocupava $443(68,9 \%)$ de seus votantes. No Matoim, onde o senador conservador João Maurício Wanderley (Barão de Cotegipe, 18151889) tinha seu antigo engenho Freguesia, estabelecido desde o século XVI, estavam registrados como votantes $52(27,2 \%)$ cidadãos ocupados na lavoura e outros $32(16,8 \%)$ na pesca.

Muitos pescadores viviam na llha de Maré, onde eles somavam 138 cidadãos alistados (69\% dos qualificados ao voto). Em Itapuã, os lavradores e os pescadores eram, respectivamente, 433 (55\%) e 214 (27\%) votantes. A caça da baleia, em particular, era praticada na Pituba (Freguesia de Brotas), Rio Vermelho e Barra (Freguesia da Vitória), na Pedra Furada (Freguesia da Penha) e em Itapuã. ${ }^{33}$

Mesmo em paróquias urbanas era possível identificar muitos votantes vivendo da agricultura e da pesca. Esse era o caso dos 106 pescadores da Vitória, que correspondiam a 15,4\% dos qualificados, e dos 198 trabalhadores da lavoura encontrados em Brotas, 25,7\% de seus cidadãos. Na Penha, havia 91 pescadores, 15,8\% dos votantes daquela freguesia. Somados, os indivíduos ocupados em atividades econômicas primárias representavam $23,2 \%$ do total de cidadãos alistados em Salvador, sendo 15\% no setor agropastoril e 8,2\% no pesqueiro.

Os grupos sociais intermediários (comerciantes e profissionais liberais) e dominantes (proprietários) reuniam aproximadamente $22,5 \%$ dos votantes da capital baiana. Ainda que distante do primeiro lugar, os comerciantes se constituíam no segundo maior grupo de cidadãos votantes de Salvador. Em função das características e atividades econômicas desenvolvidas no local, a presença e o peso deles eram muito acentuados na Cidade Baixa. Em 1859, 243 negociantes, isto é, 24,4\% dos moradores locais estavam

32 Sobre os engenhos de açúcar no Recôncavo, cf. SCHWARTZ, Stuart B. Segredos internos: engenhos e escravos na sociedade colonial. São Paulo: Companhia das Letras, 1995 (as citações são das páginas 228 e 230); BARICKMAN, Bart J. Um contraponto baiano: açúcar, fumo, mandioca e escravidão no Recôncavo, 1780-1860. Rio de Janeiro: Civilização Brasileira, 2003, cap.1; BARICKMAN, Bart. J. Até a véspera: o trabalho escravo e a produção de açúcar nos engenhos do Recôncavo baiano (1850-1881). Afro-Ásia, Salvador, n.21-22, p.177-238, 1998-1999.

33 Sobre o assunto, cf. CASTELLUCCI JUNIOR, Wellington. Caçadores de baleia: armações, arpoadores, atravessadores e outros sujeitos envolvidos nos negócios do cetáceo no Brasil. São Paulo: Annablume, 2009. 
registrados como votantes no Pilar. A Penha tinha 164 comerciantes alistados, $28,5 \%$ de seus habitantes. Nos Mares e na Conceição da Praia, eles eram 34 (7,5\%) e $25(27,8 \%)$.

$\mathrm{Na}$ Cidade Alta o quadro não era muito diferente. O impressionante número de 350 comerciantes representava $27,2 \%$ dos 1.284 votantes de São Pedro em 1876. No Santo Antonio eles eram 177, isto é, $21,3 \%$ dos residentes em 1853. Números absolutos menores foram encontrados em outras paróquias dessa área: 50 (13,9\%) na Sé, 82 (22,8\%) no Paço e 35 $(18,3 \%)$ em Santana. Muitos comerciantes foram registrados para votar nas freguesias semirrurais da Vitória e de Brotas, onde identificamos 138 $(20,1 \%)$ e $86(11,2 \%)$ votantes desse tipo, respectivamente.

Além de terem presença marcante e relevante no jogo eleitoral do Império na qualidade de votantes, os trabalhadores estavam mobilizados como elegíveis e eleitores, isto é, cidadãos plenos, que podiam votar, também, nas eleições de segundo grau, nas quais se escolhiam, efetivamente, os representantes da nação.

Como se pode ver na Tabela 3, em 1873, Salvador possuía apenas 273 eleitores, correspondente a 0,2\% de seus 134.109 habitantes. Em 1872, segundo o já citado Recenseamento, o Brasil tinha uma população de 9.930.478 de pessoas, e o número de eleitores do país foi fixado em 24.114 no ano de $1876 .{ }^{34}$ Cruzando os dois dados, temos um percentual de $0,2 \%$, ou seja, o percentual de cidadãos plenos achados em Salvador era igual ao existente no Brasil como um todo, o que nos permite concluir que, apesar da abertura à participação popular nas eleições primárias, o efetivo poder de escolha estava nas mãos de um minúsculo corpo de cidadãos, cujas dimensões não parecem variar de modo significativo quando comparamos o mundo rural e o urbano. 
Tabela 3

Número de eleitores de Salvador por freguesia (1873)

\begin{tabular}{|c|c|c|c|}
\hline FREGUESIAS URBANAS & 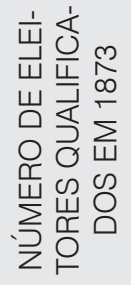 & 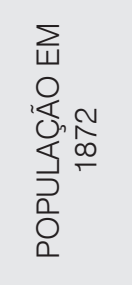 & 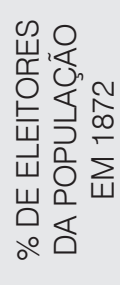 \\
\hline SÃO SALVADOR DA SÉ & 29 & 15.111 & 0,2 \\
\hline SÃO PEDRO VELHO & 21 & 14.743 & 0,1 \\
\hline SANTÍSSIMO SACRAMENTO DE SANTANA & 28 & 17.954 & 0,2 \\
\hline NOSSA SENHORA DA VITÓRIA & 25 & 11.666 & 0,2 \\
\hline NOSSA SENHORA DA CONCEIÇÃO DA PRAIA & 14 & 5.490 & 0,3 \\
\hline SANTÍSSIMO SACRAMENTO DO PILAR & 28 & 8.346 & 0,3 \\
\hline SANTÍSSIMO SACRAMENTO DA RUA DO PAÇO & 7 & 3.636 & 0,2 \\
\hline NOSSA SENHORA DOS MARES & 9 & 3.722 & 0,2 \\
\hline SANTO ANTONIO ALÉM DO CARMO (1 e $2^{\circ}$ DISTRITOS) & 27 & 16.613 & 0,2 \\
\hline NOSSA SENHORA DA PENHA DE ITAPAGIPE & 12 & 5.767 & 0,2 \\
\hline NOSSA SENHORA DE BROTAS & 11 & 5.090 & 0,2 \\
\hline FREGUESIAS SUBURBANAS & 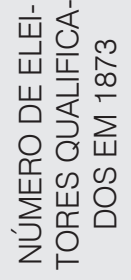 & 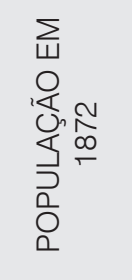 & 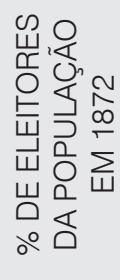 \\
\hline SÃO BARTOLOMEU DE PIRAJÁ & 8 & 2.863 & 0,3 \\
\hline SANTANA DA ILHA DE MARÉ & 4 & 1.124 & 0,4 \\
\hline NOSSA SENHORA DA PIEDADE DE MATOIM & 6 & 2.446 & 0,2 \\
\hline $\begin{array}{l}\text { NOSSA SENHORA DA COCEIÇÃO DE ITAPUÃ ( } 1^{\circ} \text { e } 2^{\circ} \\
\text { DISTRITOS) }\end{array}$ & 15 & 4.935 & 0,3 \\
\hline SÃO MIGUEL DE COTEGIPE & 6 & 2.052 & 0,3 \\
\hline NOSSA SENHORA DA ENCARNAÇÃO DE PASSÉ & 14 & 4.443 & 0,3 \\
\hline NOSSA SENHORA DO Ó DE PARIPE & 9 & 8.108 & 0,1 \\
\hline TOTAL & 273 & 134.109 & 0,2 \\
\hline
\end{tabular}

Fontes: IBGE - Recenseamento Geral do Brazil em 1872 - Bahia. Disponível em: < http://biblioteca.ibge. gov.br/> Acessado em: 1 out. 2007; Almanak administrativo, commmercial e industrial da província da Bahia para o anno de 1873, qüinquagésimo segundo da Independência e do Império. Compilado por Albino Rodrigues Pimenta, Bacharel em Direito e Chefe de Seção da Secretaria da Presidência, Anno I, Bahia: Typographia de Oliveira Mendes \& C., 1872. 
É preciso assinalar que o efetivo controle do poder político do Brasil Império estava nas mãos de uma minoria de seus cidadãos. Essa oligarquia baseava seu poder na plantation e nas atividades mercantis. A participação dos trabalhadores, tão ampla como votantes, era reduzidíssima como elegíveis e eleitores. Analisemos novamente as listas eleitorais, só que agora contabilizando o percentual de cidadãos plenos por grupo ou classe social. No conjunto da classe trabalhadora, os artesãos constituíam o maior número de cidadãos plenos. Na Sé, dos 166 operários registrados como votantes em 1876, 162 também eram elegíveis. Na Penha, 373 trabalhadores de ofício estavam registrados para votar nas eleições primárias em 1877. Deste total, 249 eram elegíveis e 124 apenas votantes.

Entre os artesãos portadores de cidadania plena nessa área, destacamos os carpinteiros Bonifácio Lopes de Souza e Guilhermino Anastácio de Souza. A trajetória de envolvimento com a política desses dois artífices começa no Império e tem seguimento sob a República, já que eles estavam na fundação do Centro Operário da Bahia, a mais importante organização política dos trabalhadores no novo regime. Na Conceição da Praia, havia o registro de 192 artífices e operários qualificados ao voto em 1876, sendo que 156 deles tinham cidadania plena e 36 eram cidadãos imperfeitos. No mesmo ano, a situação era bem diferente na Rua do Paço, já que 134 dos 166 operários alistados podiam votar apenas nas eleições primárias. Ainda assim, entre os poucos artesãos com cidadania plena, constava o nome do alfaiate João Pessoa de Brito, figura importante na fundação do Partido Operário e da União Operária em 1890 e do Centro Operário em 1893-1894. Na longínqua Itapuã, 95 dos 115 operários registrados como votantes em 1880 também poderiam ser eleitores, caso dispusessem do apoio e dos votos necessários. Mas na igualmente distante paróquia açucareira do Matoim apenas seis dos 114 artesãos alistados para votar nas eleições primárias em 1878 também poderiam se candidatar a eleitores. Um aspecto que chama atenção nesta segunda lista de votantes do Matoim, considerando que esta era uma área rural, para a qual não há registro de fábricas instaladas, é que dos 114 artesãos habilitados ao voto, 85 eram artífices sapateiros. Destes, 81 votavam apenas nas primárias e somente quatro decidiam o futuro do país. ${ }^{35}$

Entre os trabalhadores do mar, o índice de cidadania plena era ínfimo em toda a cidade. Na Conceição da Praia, dos 95 marítimos registrados em 1876, 67 eram inelegíveis. No mesmo ano e local, dos 40 saveiristas inscritos para votar nos pleitos de primeiro grau, tínhamos 22 elegíveis. Na Penha, em 1877, dos 139 pescadores votantes, apenas 48 podiam se

35 Lista geral apurada pela Junta Municipal da Capital da Bahia dos cidadãos aptos para votarem e serem votados na Paróquia de Matoim, do município da capital, de conformidade com o Art. 60, n. 1 das instruções de 12 de janeiro de 1876. Correio da Bahia, Salvador, 16 jul. 1878, p.3; Correio da Bahia, Salvador, 17 jul. 1878, p.2 e 3. 
eleger. Em Itapuã, existiam 215 pescadores qualificados em 1880, mas só quatro eram cidadãos plenos.

Com os trabalhadores rurais a situação era ainda pior. Eles estavam praticamente excluídos da cidadania plena. Em Itapuã, uma grande massa de 429 trabalhadores da lavoura estava habilitada ao voto nos pleitos que escolheriam os eleitores. Todavia, tão somente 23 deles poderiam ser eleitos. No Matoim, a situação não era muito diferente. Somente quatro dos 69 trabalhadores rurais possuíam cidadania plena.

A condição das classes médias e dominantes discrepava radicalmente. A maioria dos profissionais liberais e dos funcionários públicos era habilitada ao voto nos dois turnos das eleições imperiais. Na Sé e na Conceição da Praia, todos os votantes desses dois grupos sociais formavam, também, o corpo de cidadãos elegíveis. No Paço e na Penha, quase todos os qualificados dessas duas ocupações detinham a cidadania plena, o mesmo podendo ser dito dos comerciantes e dos proprietários dessa localidade. Todos os votantes desses dois estratos eram elegíveis nas paróquias da Sé e da Conceição da Praia. Na Penha, estavam registrados 149 comerciantes, 107 como elegíveis e 42 apenas como votantes. Os treze proprietários dessa freguesia formavam o corpo de detentores de direitos políticos irrestritos, inclusive o Barão de Cotegipe, que tinha seu engenho no Matoim, mas votava na Penha. No Paço, todos os proprietários eram cidadãos plenos e apenas treze dos 84 comerciantes não podiam se candidatar.

Em Itapuã e no Matoim, o quadro não era diferente. Nesta última freguesia, chama atenção na lista eleitoral o nome do cidadão Jeronymo Sodré Pereira, médico, professor da Faculdade de Medicina, proprietário e político, fundador da Sociedade Abolicionista 2 de Julho, contando 61 anos e renda anual de dez contos de réis em 1878. Seu pai foi o senhor de engenho e coronel de milícias Francisco Maria Sodré Pereira, proprietário do escravo (depois liberto) africano Domingos Sodré, cuja trajetória foi tirada do anonimato por João José Reis. Jeronymo Sodré Pereira era sobrinho homônimo de um rico mestre-de-campo, proprietário de um morgado em Portugal. ${ }^{36}$

Já examinamos como o voto operário cumpria um papel diferenciado e tinha um peso igualmente distinto nos pleitos imperiais. Vimos que nas eleições primárias havia uma abertura relativamente ampla à participação dos trabalhadores, mas era bastante restrita quanto aos que poderiam se candidatar a eleitor ou representante da nação. Examinemos agora alguns casos de candidaturas operárias apresentadas aos eleitores através dos partidos políticos das elites imperiais.

36 BRITO, Jailton Lima. A Abolição na Bahia: 1870-1888. Salvador: CEB-UFBA, 2003, p.106-107; REIS, João José. Domingos Sodré, um sacerdote africano. São Paulo: Companhia das Letras, 2008, p.59-60; p.371-372; p.375-376. 
Em 1876, o Partido Liberal apresentou várias chapas de candidatos a eleitores, juízes de paz e vereadores nas eleições que seriam realizadas naquele ano, entre os quais se encontravam vários artífices. A chapa apresentada aos votantes de São Pedro continha 22 candidatos a eleitores, entre os quais dois artesãos: o capitão da Guarda Nacional José Luiz Soares Sobrinho e Eduardo Soares da Silva Campos (1846-1906). ${ }^{37}$ Este último serviu ao Brasil na Guerra do Paraguai como alferes do $1^{\circ}$ Batalhão da Guarda Nacional, sendo um dos principais organizadores da Liga Operária Bahiana em 1876. Também estava presente na fundação da Irmandade de Nossa Senhora da Conceição do Tororó e integrou o Partido Operário em 1890. Ele parece ter saído da Liga Operária pouco tempo depois que a criou, sendo nomeado oficial de $1^{\mathrm{a}}$ classe da oficina de carapina do Arsenal de Marinha, depois ascendendo aos postos de mandador, contramestre e mestre de carapina dessa instituição até o momento de sua extinção.

Encontramos artesãos compondo chapas do Partido Liberal para concorrer às eleições municipais em várias freguesias, onde outros artistas liberais sobreviveram à queda do Império e integraram as organizações operárias da Primeira República. Esse foi o caso do tipógrafo pardo Ignácio Hermogenes Cajueiro (1843-1906), que em 1876 foi candidato a eleitor na chapa do Partido Liberal da freguesia de Santo Antonio, tendo composto os quadros da Associação Tipográfica Baiana, fundada em 1870, do Partido Operário e de seu sucessor, o Centro Operário. Também foi o caso do alfaiate José Roque Pinto (1840-1894), proprietário de sua própria oficina, e do mestre de construção e capitão da Guarda Nacional Pedro Augusto da Silva que, em 1876, foram candidatos a eleitores nas chapas do Partido Liberal de Santana e da Sé, respectivamente, e sob a República, pertenceram ao Partido Operário e ao Centro Operário. ${ }^{38}$

O Partido Conservador também incluiu artesãos em suas chapas de candidatos a eleitores nos pleitos imperiais. Em nossa pesquisa, conseguimos localizar várias nominatas conservadoras de 1878. Nesse ano, os conservadores apresentaram 25 candidatos a eleitores na Sé, sendo seis profissionais liberais, cinco comerciantes, três proprietários, três capitalistas, um pároco, um escrivão, três empregados e três artesãos. Em Santana foram lançados os nomes de 28 conservadores, dos quais nove eram comerciantes, três proprietários, quatro profissionais liberais, três empregados públicos, cinco empregados no comércio e dois artesãos. Havia ainda um oficial honorário e um sacerdote. Em São Pedro, 22 conservadores se candidataram a eleitores, onze comerciantes, dois proprietários, cinco profissionais liberais, um empregado da Assembleia Legislativa e outro do Banco da Bahia, um escrivão

37 Diário da Bahia, Salvador, 14 set. 1876, p.2.

38 Diário da Bahia, Salvador, 14 set. 1876, p.2. 
do Júri e apenas um artesão. ${ }^{39}$ No Paço, foram apresentados apenas seis nomes, sendo quatro comerciantes e dois artesãos. Um deles era o alfaiate João Pessoa de Britto, que sob a República se engajará na fundação do Partido Operário e do Centro Operário. Na Conceição da Praia, a lista de candidatos a eleitores conservadores era formada por um procurador, um empregado público, um escrivão, dois comerciantes e três artesãos. Uma "Chapa Oposicionista" com 27 candidatos a eleitores foi apresentada aos votantes da freguesia de Santo Antonio. Dela faziam parte nove comerciantes, um proprietário, um professor, um empregado público e nada menos que quinze artesãos, mais de metade da nominata. ${ }^{40}$

É difícil dizer o quanto os trabalhadores foram bem-sucedidos em seu envolvimento com a política, enquanto candidatos, independente do partido ao qual estivessem vinculados. Certamente, alguns conseguiram votos suficientes para galgar a condição de eleitores. Para identificá-los, fizemos uso dos editais da Justiça de Paz, por meio dos quais eram convocados os eleitores das freguesias da cidade para a confecção das listas gerais de votantes de suas respectivas paróquias. Em seguida, cruzamos com nosso banco de dados contendo informações sobre a trajetória de pouco mais de mil operários nascidos no século XIX. A partir desse procedimento, conseguimos localizar vários artesãos dotados de cidadania plena em Salvador no ano de 1878.

Em São Pedro, o artífice Eduardo Campos, que em 1876 havia sido candidato a eleitor pelo Partido Liberal, constava como um dos suplentes de eleitores daquela paróquia em 1878. ${ }^{41}$ Nos Mares, Antonio Bento Guimarães (1851-1907), mestre ferreiro da oficina de obras brancas do Arsenal de Guerra da Bahia, mestiço, conseguiu se eleger eleitor e ocupava posição importante no processo de qualificação dos votantes daquela paróquia em

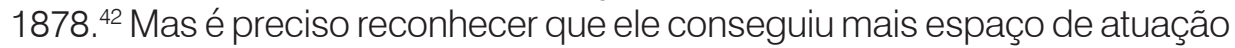
sob a República, quando tomou parte na fundação do Partido Operário, compôs a mesa eleitoral dos Mares no pleito para a Constituinte de 1890 e se elegeu juiz de paz de sua paróquia em 1899 numa complexa aliança entre o Centro Operário e o Partido Republicano Federalista.

Em Santana, o alfaiate José Roque Pinto (1840-1894), que possuía uma oficina de mesmo ofício na Rua Conselheiro Dantas, candidatou-se a eleitor pelo Partido Liberal em 1876 e encontrava-se na condição de cidadão dotado de poder para escolher os representantes da nação em 1878. Como

39 Correio da Bahia, Salvador, 1 ago. 1878, p.2.

40 Correio da Bahia, Salvador, 4 ago. 1878, p.2.

41 Correio da Bahia, Salvador, 8 jan. 1878, p.1.

42 Correio da Bahia, Salvador, 8 jan. 1878, p.1. 
outros tantos de seus companheiros, ele também estava na fundação do Partido Operário em 1890. No Paço, o alfaiate João Pessoa de Britto, que havia se candidatado pelo Partido Conservador, conseguiu sufrágios em quantidade satisfatória para ser alçado à condição de eleitor do Império. Em 1890, engajou-se na fundação e na direção do Partido Operário e da União Operária e compôs a mesa eleitoral da eleição que escolheria os deputados e senadores que redigiriam a primeira Constituição da República. ${ }^{43}$

\section{Considerações finais}

Podemos concluir afirmando que nosso estudo revelou uma face bem pouco conhecida da história do Brasil Império ao destacar que os trabalhadores se envolveram intensamente com a grande política no século XIX com vistas à aquisição de direitos políticos e sociais. Por outro lado, é preciso reconhecer que a ação da classe operária não abalou o poder econômico e a dominação política dos proprietários rurais e, secundariamente, dos comerciantes e profissionais liberais. Conquanto uma impressionante quantidade de artífices estivesse alistada como votantes, a maioria deles não poderia se candidatar a eleitores.

Adicionalmente, devemos lembrar que mesmo aqueles artesãos que dispunham das condições legais para a aquisição da cidadania plena, ou seja, eram elegíveis, frequentemente foram malsucedidos em suas tentativas de alcançar um cargo eletivo em função das injunções da política da época. Os relativamente poucos trabalhadores qualificados que conseguiram superar a condição de simples votantes das eleições primárias não parecem ter conseguido nada acima da condição de eleitores de segundo grau. Os cargos de deputados provinciais e gerais e senadores estavam nas mãos dos ricos políticos de carreira ligados aos partidos tradicionais. A despeito das formalidades constitucionais e das eleições periódicas, que garantiam uma aparência de democracia e legalidade ao país, o Brasil Império era um sociedade na qual o poder político estava concentrado nas mãos de uma oligarquia proprietária de terras e escravos, muito pouco afeita à participação popular.

A mudança mais profunda e de percepção e alcance mais rápido no que diz respeito à cidadania política ocorreu a partir de 9 de janeiro de 1881, quando foi aprovada a chamada Lei Saraiva. O novo sistema suprimiu a eleição indireta, em dois turnos, extinguiu a categoria de votante e manteve apenas a de eleitor. A eleição dos deputados gerais e provinciais passou a

43 Correio da Bahia. Salvador, 16 jan. 1878, p.1; Pequeno Jornal. Salvador, 18 ago. 1890, p.2. Sobre as organizações operárias citadas e seu envolvimento com as eleições na Primeira República, cf. CASTELLUCCI, Aldrin A. S. Política e cidadania operária em Salvador (1890-1919). Revista de História, São Paulo, n.162, p.205-241, $1^{\circ}$ semestre de 2010; CASTELLUCCI, Aldrin A. S. Trabalhadores, máquina política e eleições na Primeira República. Salvador: UFBA, 2008 (História, Tese de doutorado). 
ser feita pelo voto distrital direto. Voltou-se ao sistema chamado de círculo de um deputado, segundo o qual cada representante do povo era eleito por maioria absoluta dos sufrágios de seu distrito. A comprovação da renda de, no mínimo, duzentos mil-réis anuais, por parte dos eleitores, tornouse mais rigorosa. $\mathrm{O}$ fato mais importante foi que o alistamento de novos eleitores ficou condicionado à alfabetização dos aspirantes a cidadãos. Essas mudanças provocaram uma radical diminuição do eleitorado. Perto de seu fim, o Império escravocrata produziu ainda mais exclusão política e criou novas dificuldades para os trabalhadores tomarem a história de seu país nas mãos e conseguirem cidadania social. Não foi sem razão que a República seduziu a classe operária de modo tão irresistível, de norte a sul do Brasil, em seus primeiros anos. 